London where coroners' inquests abound. Both would prove that his position is an absolntely false one, brought about by the deplorable attitude which he and his fellow anæsthetists still maintain towards the work of the Hyderabad Commission. Dr. Hewitt affects with some show of confidence to shelter himself behind the "scientific world" in this matter, but even he cannot have failed to notice that, though the world of science is particularly well able to speak for itself, it has been singularly reticent on the subject of anæsthetics ever since the Cambridge contingent of its representatives cut such a very poor figure at the great meeting of the British Medical Association in Montreal.

I am, Sirs, yours faithfully,

March, 1901. EDWARD LAWRIE.

\section{STATISTICS OF OPERATIONS ON THE KIDNEY.}

To the Editors of THE LANOET.

SIRS,-In an endeavour to make a collection of renal operations performed $\mathrm{u} \rho$ to the end of the last century I am desirous that the statistics should be as complete as possible and made to include not only those cases the records of which are known, but also unpublished cases. May I therefore venture through your columns to ask operators to assist me by sending to me a complete list of their operations up to Dec. 31st, 1900, giving particulars in the following order :-(1) Number; (2) date of operation; (3) name of operator, and if the case has been published, where; (4) sex and age of patient; (5) nature of operation; (6) diagnosis of disease; (7) duration of disease ; (8) diseased condition as ultimately determined; (9) immediate result; and (10) ultimate result.

Fourteen years ago I made a similar appeal and in response received records of a large number of valuable unpublished cases, also details as to the ultimate result of many others the earlier history of which had been made known. Encouraged by the hearty cöoperation formerly accorded I now appeal to a greatly increased field of workers for help in demonstrating the position to which renal surgery has attained.

I am, Sirs, yours faithfully, DaVID NeWMaN.

Royal Infirmary, Glasgow, March 2lst, 1901.

PS.--Schedules will be supplied on application to my resident assistant at the Glasgow Royal Infirmary.-D. N.

\section{"THE ORGANISATION OF THE PROFESSION."}

To the Editors of THE LANCET.

SIRS, - I should like to say a few words on the above subject which is introduced in THE LANCEN of March 23rd, p. 894, by " A General Practitioner." It is over two years ago since the medical men practising in the eastern valley of Monmouthshire found it necessary to organise themselves into an association chiefly with the object of getting better pay, and to that end a circular was printed and sent to the various collieries and works by the surgeons attending them. Up to that time the medical attendant was paid at the rate of $2 d$. in the $£$ of the weekly earnings, and the medical attendant was to provide medicine, medical attendance, undertake all accidents and operations. and provide appliances to the workman, his wife, and family. Midwifery was the only thing paid specially for, and that was expected to be attended for a fee of $10 s$. $6 d$. irrespectively of the nature of the case or the distance away. Immediately the notices went forth to the various works from the doctors asking for the advance of $1 d$. in the $£$ an angry growl rose from the mass of workmen and many meetings were held the collier especially being the most dissatisfied and endeavouring to make a good bargain for himself by stating that if he advanced the doctor's pay $1 d$. in the $£$ he must have a quid pro quo in the shape of linseed meal, cod-liver oil, and free midwifery, thoroughly disregarding the fact that we had attended all through the five months' coal strike withont a farthing remuneration and, as we had pointed out in our circular letter, that the advance in assistants' salaries and other things connected with the profession made it imperative that our pay should be increased. We made up our minds distinctly that we could not supply cod-liver oil and linseed-meal, neither would we give free midwiferr, although we knew that in the western valley and some other places in the South Wales coal district these three things had been conceded, as well as free attendance on venereal diseases. We had met the British workman with his own weapon and, strange to say, he did not appreciate it-viz., a trade-union, and the only thing wo had to fear was the introduction of strangers into our midst. This was threatened, and one of our members acting rather precipitately resigned. His resignation was accepted and an advertisement was inserted in a local paper for a successor to his appointment, and, notwithstanding the fact that by a counter advertisement we asked applicants to communicate with our secretary before applying for the post, no less than 25 medical men made application for the position, which I may add was only a very small affair. In the organisation of the profession what is required is that medical men, and the junior members especially, should band themselves together in one union to resist the great tendency there is to reduce our remuneration. The junior members should stand by and allow us to fight the battle which in the years to come will be for their benefit. Daring the past two or three years the junior members have benefited in a financial way by the action of their seniors, and if they will only help us by keeping aloof from applying for posts they know to be vacan $t$ in consequence of some disagreement with the original holder until they know the exact position of affairs they will benefit the profession at large and raise our status socially. I may add that after several months of hard fighting we gained the $1 d$. advance we asked for without supplying free cod-liver oil and linseed-meal, but we had to make a con. cession with respect to the mid wifery, inasmuch as we agreed to attend any workman's wife in her confinement for the usual half-guinea providing we were engaged beforehand and a proper nurse were in attendance; but, at the same time, if any woman was being attended by $a$ midwife and any difficulty arose that she could not manage we agreed to give free attendance. This was called emergency midwifery. This arrangement has now been going on nearly two years and works very well. - I am, Sirs, yours faithfully,

S. Butler Mason, M.R.C.P. Edin., \&c.

President of the Eastern Valley Medical Association, Monmouthshire.

Pontypool, Mon., March 20th, 1901.

\section{DEAFNESS IN BOARD SCHOOL CHILDREN.} To the Editors of THE LANCET.

SIRs, - The question of diminishing the amount of deafness in children through the agency of school boards having been raised in THE LANCET of March 16th, perhaps the method adopted in the Halifax schools, though without any claim to originality, may have some interest. Fach class is visited by the medical officer for this purpose, and all "mouthbreathers" and children thought by the teachers to be deaf are examined by him. Printed notices are subsequently sent to the parents of those suffering from adenoids advising them to seek medical treatment either privately or in hospital. In a few cases of otorrhœa a similar notice is sent, but in the majority of these cases the parent is simply warned of the dangers of the condition and advised to syringe the ears daily. Doubtless it would be better to have these cases also under medical supervision, but now and until the poorer classes regard otorrhœa more seriously advice to this effect would be largely thrown away and the moral effect of the notices gradually destroyed. I may add that with the increased attention paid to breathing exercises and the repression of mouth-breathing it is hoped that the number of adenoid cases will be much diminished. The method is no doubt crude but it certainly results in the "cure" of a fair number of cases and a great diminution in the number of offensive aural discharges; it gives rise also to an increased disposition on the part of parents to seek treatment for their children in ear affections which they formerly regarded as of little moment or beyond remedy, and while there are obvious objections to an educational body taking up the actual treatment of disease the education of children or their guardians in the importance of personal hygiene may fairly be claimed as one of their duties. I am, Sirs, yours faithfully,

T. H. HUNT, M.D. Lond.

March 20th, 1901. Medical Officer to the Halifax School Board.

BEER-POISONING.

To the Editors of THE LANCET.

SIRs, - Those who drink beer have been rather startled of late by ascertaining that there are disease and death in this 